\title{
Structural, Magnetic and In Vitro Bioactivity of Co-Cu Ferrite and Bioglass Composite for Hyperthermia in Bone Tissue Engineering
}

\author{
Sampath KA, Himanshu T, Kevin B and Singh SP*
}

Department of Ceramic Engineering, Indian Institute of Technology (Banaras Hindu University), Varanasi, India

\begin{abstract}
Magnetic induction hyperthermia is emerging for cancer treatment with bioceramic materials rather radiotherapy and chemotherapy. Copper substituted cobalt ferrites as $\mathrm{Co}_{1-\mathrm{x}} \mathrm{Cu}_{\mathrm{x}} \mathrm{Fe}_{2} \mathrm{O}_{4}$ (where $\mathrm{x}=0.2,0.4,0.6,0.8$ ) ware prepared through self-propagating high-temperature synthesis (SHS) and the effect of copper on the structural, magnetic and biological properties was investigated. XRD revealed the formation of solid solution and the magnetic measurements showed the formation of soft ferrites as compared to $\mathrm{CoFe}_{2} \mathrm{O}_{4}$. The bioactive composite was prepared by incorporating the ferrite having optimum magnetic properties with bioactive glass and the constituent phases in the sintered composite were analyzed by X-ray diffraction (XRD). The bioactive composite comprised of $\mathrm{Na}_{2} \mathrm{Ca}_{2} \mathrm{Si}_{3} \mathrm{O}_{9}$ phase in solid solution. In vitro bioactivity of the composite was investigated in simulated body fluid (SBF) under physiological conditions. The precipitated hydroxy carbonated apatite (HCA) layer was confirmed by Fourier Transform Infra-Red spectrometer (FTIR), scanning electron microscopy (SEM) and XRD techniques. Cell viability and cytotoxicity against osteoblast MG63cell lines exhibit that the composite is cytocompatible.
\end{abstract}

Keywords: $\mathrm{Cu}-\mathrm{Co}$ ferrite composite; Bioactive glass; Magnetization; Cell culture; Bioactivity

\section{Introduction}

Nanocrystalline ferrites are one of the current area of interest because of their wide application in industries as well as research. They are attractive as they are important in fields like ferro-fluids, magnetic drug delivery, hyperthermia for cancer treatment, etc. [1-4] Magnetic induction hyperthermia is a new area of research for treatment of cancer tumour. Murase during their investigation observed that the use of an external static magnetic field (SMF) with a field free point (FFP) would be effective in controlling the temperature rise in magnetic hyperthermia $(\mathrm{MH})$ in order to reduce the risk of heating and damaging the surrounding healthy tissues [5]. Therefore, the hyperthermia is expected to cause the least damage to the living tissues in the human body during treatment in comparison to radiotherapy, chemotherapy and the removal of the entire mass by surgery [6]. Predominantly, under an alternative magnetic field, this material can kill the cancer cells due to heat generated by loss of magnetic hysteresis $[7,8]$. Thus, themagnetic nanoparticles are used in a specific area, where the tumour is located and it moderatesthe heat distribution. This method has a unique feature, which includes a specific targeted area, short heating time, even distribution and safe application. The $\mathrm{CoFe}_{2} \mathrm{O}_{4}$ which has got peculiar properties like high saturation magnetization $\left(\mathrm{M}_{\mathrm{s}}\right)$, high coercivity $\left(\mathrm{H}_{\mathrm{c}}\right)$ and large anisotropy [9]. Amiri and Shokrollahi had reviewed the successful application of cobalt ferrite in different areas like ferrofluids technology, microwave devices, biomedical drug delivery, magnetic resonance imaging, data storage, biosensors, magneto-optical devices and biocompatible magnetic nanoparticles for cancer treatment[10]. Therefore, the present work is aimed for hyperthermia application in the field of biomedical for which a low saturation magnetization material is essentially required; thus, the copper has chosen to substitute in cobalt ferrite. $\mathrm{CoFe}_{2} \mathrm{O}_{4}$ has an inverse spinel structure with $\mathrm{Co}^{2+}$ ions in octahedral sites and $\mathrm{Fe}^{3+}$ ions are equally distributed between tetrahedral and octahedral sites [11]. $\mathrm{CuFe}_{2} \mathrm{O}_{4}$ also crystallizes in an inverse spinel structure with $\mathrm{Cu}^{2+}$ ions in distorted octahedral and $\mathrm{Fe}^{3+}$ being equally distributed in tetrahedral and octahedral sites, but the magnetic moment and ionic radius of $\mathrm{Cu}^{2+}$ is different from $\mathrm{Co}^{2+}$ ions [12,13]. Therefore, substitution of $\mathrm{Cu}$ in $\mathrm{CoFe}_{2} \mathrm{O}_{4}$ may create distorted spinel structures depending upon the concentration of the precursor solutions. As the magnetic properties and ionic radius of $\mathrm{Cu}^{2+}\left(3 \mathrm{~d}^{9}\right)$ is different from $\mathrm{Co}^{2+}\left(3 \mathrm{~d}^{7}\right)$, so some changes in the magnetic and structural properties of mixed ferrites were expected upon substitution of $\mathrm{Cu}$ in $\mathrm{CoFe}_{2} \mathrm{O}_{4}$. Hashim has demonstrated that that the lattice parameter (a) decreased with an increase in copper concentration in cobalt-copper ferrite. Further, they also observed that the saturation magnetization decreased with increasing $\mathrm{Cu}^{2+}$ ion substitution in the system. Another study by Sanpo showed that the copper-substituted cobalt ferrites has a cubic spinel structure and the particle size decreased with increasing concentration of copper in the system [14]. Moreover, the antibacterial activity against E. coli was slightly improved by the substitution of $\mathrm{Cu}$ in cobalt ferrite, but, it enhanced the antibacterial activity significantly against $S$. aureus. Sanpo also studied with transition metals of copper, zinc, chromium and nickel were substituted into cobalt ferrite and they reported that copper substituted cobalt ferrite nanoparticles have showed the most effective antibacterial against on both the $E$. coli and $S$. aureus amongst all [15]. These studies clearly depict that the copper substituted cobalt ferrite is very much beneficial for biomedical application especially in hyperthermia because of the fact that it exhibited low saturation magnetization and antibacterial activity.Similar investigations were also made by Singhal regarding the effect of $\mathrm{Zn}$ substitution on magnetic properties of cobalt ferrite nano particles and it was found that saturation magnetization increased from $\mathrm{CoFe}_{2} \mathrm{O}_{4}$ to $\mathrm{Co}_{0.6} \mathrm{Zn}_{0.4} \mathrm{Fe}_{2} \mathrm{O}_{4}$ and then decreased till $\mathrm{ZnFe}_{2} \mathrm{O}_{4}$ at the cost of Co [16]. Islam reported on saturation magnetization that a decreasing behavior with zinc

*Corresponding authors: Singh SP, Department of Ceramic Engineering, Indian Institute of Technology (Banaras Hindu University), Varanasi221005, India, Tel:0542 236 8106; E-mail: spsinghceram@gmail.com

Received December 03, 2015; Accepted January 28, 2016; Published February 04, 2016

Citation: Sampath KA, Himanshu T, Kevin B, Singh SP (2016) Structural, Magnetic and In Vitro Bioactivity of Co-Cu Ferrite and Bioglass Composite for Hyperthermia in Bone Tissue Engineering. Bioceram Dev Appl 6: 091. doi:10.4172/2090 5025.100091

Copyright: (c) 2016 Sampath KA, et al. This is an open-access article distributed under the terms of the Creative Commons Attribution License, which permits unrestricted use, distribution, and reproduction in any medium, provided the original author and source are credited. 
concentration in cobalt-zinc ferrites[17]. Vaidyanathan also reported a decrease in magnetic properties such as $\mathrm{M}_{s}, \mathrm{H}_{\mathrm{s}}, \mathrm{H}_{\mathrm{c}}$ and $\mathrm{M}_{\mathrm{r}}$ with an increase in zinc substitution [18]. The diamagnetic nature of $\mathrm{Zn}^{2+}$ ions was credited to this decrement in magnetic properties. Therefore, the magnetic properties of the particles rely on the crystal structure and site occupancy whilst the biological response properties rely mainly on the innate properties of the bioactive glasses.

On the other hand, bioactive glasses have been widely investigated for bone repair because of their outstanding bioactivity and biological properties [19]. Hench made a glass composition (45S5 Bioglass $\left.{ }^{\circ}\right) 46.1$ $\mathrm{SiO}_{2}, 24.4 \mathrm{Na}_{2} \mathrm{O}, 26.9 \mathrm{CaO}$ and $2.6 \mathrm{P}_{2} \mathrm{O}_{5}$ (mole \%), the bioactive materials undergo complete conversion into a bone-like material and strongly bond to living bones through an hydroxy apatite (HA) layer formed on their surfaces [20]. The addition of bioglass in the ferrite composite can bond to the bone through a biologically active hydroxy carbonate apatite (HCA) layer on the surface of the weakened tumorous bone. Composites have got some porous structure and this is very important for tissue engineering as it enables to provide nutrients and metabolic wastes for the surrounding bone tissues via ingrowth of mineralized tissues into the porous space [21]. The addition of bioglass in the ferrite shows some kind of biodegradability and also supports better osteoblasts growth in vitro. The ferrites alone have got their limited applications for tissue engineering due to their inertness towards bioactivity and release of certain toxic elements into the human body. Further, the leaching of ferrite particles and their migration into the human body fluid can be controlled due to encapsulation of ferrite particles by glass matrix.Furthermore, $\mathrm{Co}-\mathrm{Cu}$ ferriteacts as antibacterial which is expected to prevent the regeneration of tumour after the treatment of cancerous cells $[14,15,22,23]$. The aim of the present work is quite different from those of the previous reports that we have prepared the ferrite sample with higher concentration of copper in the cobalt ferrite system. Further, the bioactive glass was added to enhance the biological properties. Therefore, the $\mathrm{Co}-\mathrm{Cu}$ ferrite and bioglass composite was prepared because of the fact that upon application of the magnetic field the ferrite turns into a magnet and results in production of heat which would destroy the carcinogenic cells. Later, the bioactive glass can also bond with surrounding hard and soft tissues. The composite is expected to be a more suitable potential biomaterial for hyperthermia application in bone tissue engineering.

\section{Experimental Procedure}

\section{Materials and methods}

Nanoparticles of copper substituted cobalt ferrites $\mathrm{Co}_{1-\mathrm{x}} \mathrm{Cu}_{\mathrm{x}} \mathrm{Fe}_{2} \mathrm{O}_{4}$ (where $\mathrm{x}=0.2,0.4,0.6$ and 0.8 ) were prepared using SHS with metal nitrates as reagents and citric acid as fuel [24] In this method each sample was prepared by taking the desired proportion of analytical reagent grade precursor nitrates, i.e., cobalt nitrate, ferric nitrate and copper nitrate which were separately dissolved in $20 \mathrm{ml}$ of double distilled water. Molar ratios between metal nitrates and the reducing agent were calculated by oxidized and reduced valence states of various elements. All the solutions were mixed together and citric acid was added as fuel for auto combustion. The solutions were evaporated with continuous stirring till gel formation on a hot plate (Heat and Stir, Glassco, India) and the hot plate temperature was set at $200^{\circ} \mathrm{C}$. Thus the formed gel ignites itself,resulting into nanoparticles of desired ferrite. These obtained ferrites were then heat treated to $1000^{\circ} \mathrm{C}$ for $2 \mathrm{~h}$.

\section{$\mathrm{X}$-ray diffraction analysis}

To infer the phases present, the fine powdered samples were subjected to X-ray diffraction analysis (XRD). A RIGAKU-Miniflex II diffractometer adopted $\mathrm{Cu}-\mathrm{Ka}$ radiation $\left(\lambda=1.5405 \mathrm{~A}^{\circ}\right)$ with a tube voltage of $40 \mathrm{KV}$ and current of $35 \mathrm{~mA}$ and was used for lattice parameters determination and phase analysis. The JCPDF-international centre for diffraction data cards was correlated.

\section{Magnetization, preparation of bioactive glass and ferrite composite}

Magnetic characterization of the particles was done using vibrating sample magnetometer (VSM, PAR-155) at room temperaturewith maximum applied field upto $15 \mathrm{kOe}$. Bioactive composite was prepared by incorporating the ferrite having optimum magnetic properties pertaining to a soft ferrite with $45 \mathrm{~S} 5 \mathrm{Bioglass}^{\circ}$. Therefore, the bioactive glass was prepared by the sol-gel method as described in elsewhere $[25,26]$. Ferrite and bioactive glass powders were mixed thoroughly in the 9:1 ratio (90\% ferrite of $\mathrm{Co}_{02} \mathrm{Cu}_{08} \mathrm{Fe}_{2} \mathrm{O}_{4}: 10 \% 45 \mathrm{~S} 5$ Bioglass ${ }^{\oplus}$ and compacted to form cylindrical pellets of $3 \mathrm{~mm}$ thickness and $10 \mathrm{~mm}$ diameter. The pellets were then sintered at $1000^{\circ} \mathrm{C}$ for $2 \mathrm{~h}$ in a muffle furnace in air atmosphere.In order to reproduce the formation of apatite on bioactive materials, in vitro was assessed using simulated body fluid (SBF) and the SBF was prepared according to the method proposed the inorganic ion concentrations of the SBF are similar to human body fluids[27].

\section{Assessment of bioactivity by FTIR spectrometry and scan- ning electron microscopy}

The in-vitro bioactivity of the composite prepared by incorporating the softest ferrite and bioactive glass was assessed by the formation of hydroxy carbonateapatite (HCA) layer on the surface of the composites after immersion in SBF solution by Fourier Transform Infra-Red spectrometer (FTIR) spectrometry. The infrared transmittance spectra of the prepared composite was recorded at room temperature in the spectral range of $4000-400 \mathrm{~cm}^{-1}$ using FTIR (Tensor 27, Bruker Optic, Germany) with a diamond ATR and a resolution of $4 \mathrm{~cm}^{-1}$. The surface morphology of composites was analyzed before and after SBF treatment using a scanning electron microscope (SEM), Inspect S50, FEI). The samples were coated with gold by sputter coating instrument before SEM analysis.

\section{In-vitro cell culture}

The in vitro cytocompatibility was assessed by cell viability and cytotoxicity of $\mathrm{Cu}$-Co ferrite bioactive glass composite using osteoblast (MG63) cell lines. The powdered sample was used for cell culture studies and the amount of the sample in the culture medium was $10 \mathrm{mg} /$ ml. MG63 cells (ATCC, USA) which resembles human osteoblast were used in the present investigation. The composite samples were sterilized in an autoclave at $121^{\circ} \mathrm{C}$ for $30 \mathrm{~min}$. MG63 cells were cultured in a minimum essential medium (MEM; Invitrogen Corporation), augmented with $10 \%$ of fetal calf serum (FCS), $1 \%$ antibiotic antimycotic solution in a humidified atmosphere at $37^{\circ} \mathrm{C}$ and with $5 \%$ $\mathrm{CO}_{2}$ for 24,48 and $72 \mathrm{~h}$. The methyl thiazolyl tetrazolium (MTT) [3-(4, 5-dimethylthiazol-2-yl)-2, 5-diphenyl tetrazolium bromide] assay was used to evaluate cell viability and cytotoxicity $[28,29]$.

\section{Results and discussion}

\section{XRD analysis of ferrites}

The samples were prepared by the SHS in which the reaction hot plate temperature was maintained at $200^{\circ} \mathrm{C}$. Figure 1 shows the XRD pattern of base $\mathrm{CoFe}_{2} \mathrm{O}_{4}$ ferrite as prepared and after sintered at $1000^{\circ} \mathrm{C}$ 


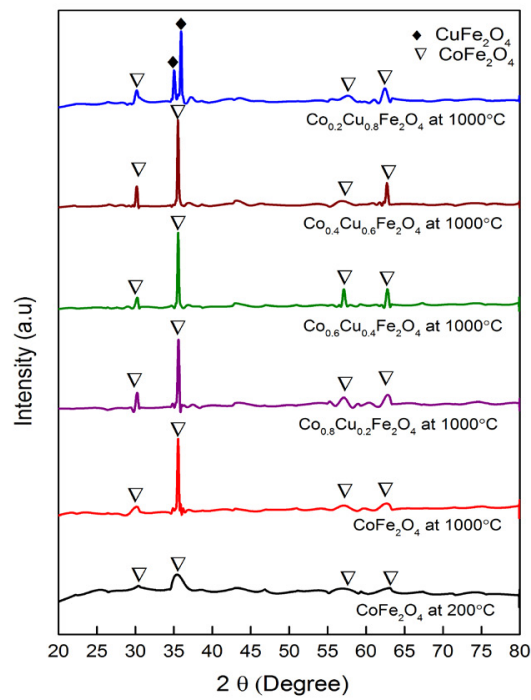

Figure 1: XRD pattern of self-propagating high-temperature synthesis $\mathrm{CoFe}_{2} \mathrm{O}_{4}$ and effect of incremental $\mathrm{Cu}$ in cobalt ferrite sintered at $1000^{\circ} \mathrm{C}$.

for $2 \mathrm{~h}$ as well as copper substituted samples. The XRD patter of the as prepared sample reveals a small hump centered at $2 \theta=35.42^{\circ}$ with a less intensity, which is regarded as an amorphous nature of the sample. However, after sintering at $1000^{\circ} \mathrm{C}$ for $2 \mathrm{~h}$, the intensity of the peak was increased with temperature and the peaks were recorded at $2 \theta=30.08^{\circ}$, $35.48^{\circ} 56.98$ and $62.58^{\circ}$, which are regarded the characteristic peaks of cobalt spinel ferrite $\left(\mathrm{CoFe}_{2} \mathrm{O}_{4}\right)$ phase and was confirmed by JCPDF card numbered \# 22-1086 [30]. In general, the increase in intensity of the peak confirms the increase in the particle size and that could be attributed due to the grain size growth of particles with an increase in temperature $[31,16]$. The above explanation has been supported by the sample XRD data, which confirms the increase in intensity of the peaks with an increase in temperature. Moreover, the samples were found to be face centered cubic (FCC) with the Fd-3m space group.

Figure 1 also represents the XRD pattern for the copper substituted samples $\mathrm{Co}_{1-\mathrm{x}} \mathrm{Cu}_{\mathrm{x}} \mathrm{Fe}_{2} \mathrm{O}_{4}$ (where $\mathrm{x}=0.2,0.4,0.6,0.8$ ) and were sintered at $1000^{\circ} \mathrm{C}$ for $2 \mathrm{~h}$. It can be clearly seen from the XRD pattern that the copper substitution up to 0.6 mole fraction in cobalt ferrite, no distinct changes in the $\mathrm{CoFe}_{2} \mathrm{O}_{4}$ phase. Thus, the concentration of copper up to 0.6 mole fraction does not influence on the main phase. Further. it is interesting to note that, after substitution of 0.8 mole fraction of copper in cobalt ferrite, the major peak of $\mathrm{CoFe}_{2} \mathrm{O}_{4}$ at $2 \theta=35.48^{\circ}$ is split into two peaks at $2 \theta=34.76^{\circ}$ and $35.86^{\circ}$, which are corresponding to major peaks of copper spinel ferrite $\left(\mathrm{CuFe}_{2} \mathrm{O}_{4}\right)$ phase and was confirmed by JCPDF card numbered \# 34-0425 [32,33]. It is to emphasize that the sample $\mathrm{Co}_{0.2} \mathrm{Cu}_{0.8} \mathrm{Fe}_{2} \mathrm{O}_{4}$ contain both phases of $\mathrm{CoFe}_{2} \mathrm{O}_{4}\left(2 \mathrm{\theta}=30.08^{\circ}, 56.98\right.$ and $\left.62.58^{\circ}\right)$ and $\mathrm{CuFe}_{2} \mathrm{O}_{4}\left(2 \theta=34.72^{\circ}\right.$ and $\left.35.86^{\circ}\right)$ as can be seen from the Figure 1. Therefore, the sample $\mathrm{Co}_{0.2} \mathrm{Cu}_{0.8} \mathrm{Fe}_{2} \mathrm{O}_{4}$ can be considered as a mixed $\mathrm{Cu}$-Co spinel ferrite in the system. Furthermore, the lattice parameters of the copper substituted samples were determinedby Powley and Le-Bail refinement methods. It was observed that the lattice parameter ' $a$ ' increased linearly with increasing concentration of copper, which are shown in Table 1 . The reason behind this increase in lattice parameter might be due to greater ionic radii of $\mathrm{Cu}^{2+}(0.87 \AA)$ as compared to $\mathrm{Co}^{2+}(0.84 \AA)$.

\section{Magnetic measurements}

The hysteresis loops of ferrites $\mathrm{Co}_{1-\mathrm{x}} \mathrm{Cu}_{\mathrm{x}} \mathrm{Fe}_{2} \mathrm{O}_{4}(\mathrm{x}=0.2,0.4,0.6$ and 0.8$)$ after sintering at $1000^{\circ} \mathrm{C}$ have been shown in Figure 2. The saturation magnetization of all the sintered samples was found to be in the range 58-79 emu/g which is less than that of $\mathrm{CoFe}_{2} \mathrm{O}_{4}$ sintered at the same temperature. The saturation magnetization of the sintered samples of $\mathrm{CoFe}_{2} \mathrm{O}_{4}$ at $1000^{\circ} \mathrm{Cis} \sim 84 \mathrm{emu} / \mathrm{g}$, this is in good agreement with earlier studies $[31,34]$. The decrement in the values of saturation magnetization with an increase in $\mathrm{Cu}$ concentration could be attributed due to the lesser ferromagnetic behavior of $\mathrm{Cu}^{2+}$ ion as compared with $\mathrm{Co}^{2+}$ ion. In a cubic system like ferromagnetic spinels, the magnetic order is mainly because of themechanism of super exchange interaction taking place in between metal ions in A and B sub lattices. The substitution of paramagnetic ions such as divalent copper having preferential a site occupancy results in an increase in the exchange interaction between $A$ and B sites [35]. Hence, on changing the concentration of copper in cobalt copper ferrites, it would be possible to vary their magnetic properties. Similar observations have been also made by Singhal [16] in case of cobalt-zinc ferrites in which amount of zinc addition was varied for cobalt resulting in a change in magnetic properties of the their samples. An another study made by G.R. Kumar et al. demonstrated the similar behavior in copper substituted nickel ferrite [32]. Furthermore, the saturation magnetization for all the ferrites after heat treatment at $1000^{\circ} \mathrm{C}$ was calculated by Neel's formula as given below.

$$
\mathrm{n}_{\mathrm{B}}^{\mathrm{N}}(\mathrm{x})=\mathrm{M}_{\mathrm{B}}(\mathrm{x})-\mathrm{M}_{\mathrm{A}}(\mathrm{x})
$$

where $M_{A}$ and $M_{B}$ are the $A$ and $B$ sublattice magnetic moment in $\mu B$, respectively.

It is evident from the results presented in Table 1 that the saturation magnetization significantly decreased from 79.2 to 58.6 $\mathrm{emu} / \mathrm{g}$ for the samples $\mathrm{Co}_{0.8} \mathrm{Cu}_{0.2} \mathrm{Fe}_{2} \mathrm{O}_{4}$ and $\mathrm{Co}_{0.2} \mathrm{Cu}_{0.8} \mathrm{Fe}_{2} \mathrm{O}_{4}$, respectively. These results are in good agreement with earlier reports demonstrated that the saturation magnetization decreased with increasing $\mathrm{Cu}^{2+}$ ion substitution in the system $[36,13]$. This may be due to incorporation of $\mathrm{Cu}^{2+}\left(3 \mathrm{~d}^{9}\right)$ ion with a bigger ionic radii $(0.87 \AA)$ and distorted octahedral symmetry which replaces $\mathrm{Co}^{2+}\left(3 \mathrm{~d}^{7}\right)$ ion having smaller ionic radii $(0.84 \AA)$ on the octahedral sites. This resulted in anincrease of magnetic moments in the sub-lattice $M_{A}$, causing in a decrease

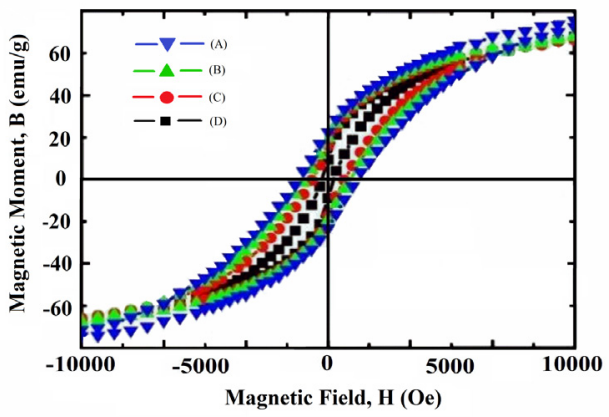

Figure 2: Hysteresis loop of the Cu-Co ferrites sintered at $1000{ }^{\circ} \mathrm{C},(\mathrm{A})$ $\mathrm{Co}_{0.8} \mathrm{Cu}_{0.2} \mathrm{Fe}_{2} \mathrm{O}_{4}(\mathrm{~B}) \mathrm{Co}_{0.6} \mathrm{Cu}_{0.4} \mathrm{Fe}_{2} \mathrm{O}_{4}(\mathrm{C}) \mathrm{Co}_{0.4} \mathrm{Cu}_{0.6} \mathrm{Fe}_{2} \mathrm{O}_{4}$ (D) $\mathrm{Co}_{0.2} \mathrm{Cu}_{0.8} \mathrm{Fe}_{2} \mathrm{O}_{4}$

\begin{tabular}{|c|l|l|c|c|}
\hline S.No. & $\begin{array}{l}\text { Molar Ferrite } \\
\text { Composition }\end{array}$ & $\begin{array}{l}\text { Lattice } \\
\text { Parameter, } \\
\mathbf{a}(\mathbf{A})\end{array}$ & Volume(a ${ }^{3}$ ) & $\begin{array}{l}\text { SaturationMagnetization } \\
\text { (emu/g) }\end{array}$ \\
\hline 1 & $\mathrm{Co}_{0.8} \mathrm{Cu}_{0.2} \mathrm{Fe}_{2} \mathrm{O}_{4}$ & 8.3931 & 591.24 & 79.2 \\
\hline 2 & $\mathrm{Co}_{0.6} \mathrm{Cu}_{0.4} \mathrm{Fe}_{2} \mathrm{O}_{4}$ & 8.4152 & 595.93 & 65.3 \\
\hline 3 & $\mathrm{Co}_{0.4} \mathrm{Cu}_{0.6} \mathrm{Fe}_{2} \mathrm{O}_{4}$ & 8.4178 & 596.48 & 62.4 \\
\hline 4 & $\mathrm{Co}_{0.2} \mathrm{Cu}_{0.8} \mathrm{Fe}_{2} \mathrm{O}_{4}$ & 8.4243 & 597.86 & 58.6 \\
\hline
\end{tabular}

Table 1:Lattice parameters derived from $\mathrm{X}$-ray diffraction pattern and saturation magnetization of the copper substituted cobalt ferrites sintered at $1000^{\circ} \mathrm{C}$ for $2 \mathrm{~h}$. 
Citation: Sampath KA, Himanshu T, Kevin B, Singh SP (2016) Structural, Magnetic and In Vitro Bioactivity of Co-Cu Ferrite and Bioglass Composite for Hyperthermia in Bone Tissue Engineering. Bioceram Dev Appl 6: 091. doi:10.4172/2090-5025.100091

of the total magnetic moment. Based on the hysteresis behavior, ferrites can be categorized into soft and hard ferrites. The ferrite $\mathrm{Co}_{0.2} \mathrm{Cu}_{0.8} \mathrm{Fe}_{2} \mathrm{O}_{4}$ is the softest ferrite amongst all, which can be easily magnetized or demagnetized, i.e. the direction of magnetization can easily be reversed as the magnetic field $(\mathrm{H})$ is removed and thus the magnetic moment (B) becomes almost zero. This behavior may be attributed due to the presence of mixed $\mathrm{Cu}$-Co spinel ferrite phases in the $\mathrm{Co}_{0.2} \mathrm{Cu}_{0.8} \mathrm{Fe}_{2} \mathrm{O}_{4}$ sample, which is confirmed by XRD data as shown in Figure 1. Therefore, this ferrite could be used as a potential material for hyperthermia application.Moreover, on application of alternating magnetic field this material can generate heat by loss of magnetic hysteresis, whichwould kill the carcinogenic cells [8]. Thus, the prepared ferrite sample can be proposed as a potential material for hyperthermia treatment of deep rooted tumors in the bones. Further to enhance the biological properties, the ferrite was mixed with $10 \%$ bioactive glass by weight followed by sintering at $1000^{\circ} \mathrm{C}$ for $2 \mathrm{~h}$ in a muffle furnace. The prepared composite expected to bond to the bone through a biologically active apatite layer on the surface of the sample and join with weaker tumorous bones.The in-vitro bioactivity of composite was assessed in SBF and cell culture studies were performed for its suitability.

\section{pH behavior in SBF}

The composite sample was immersed in SBF for various time periods up to 7 days and the variation in $\mathrm{pH}$ of the reacted SBF with time intervals has been shown in the Figure 3. The graph shows an initial increase in the $\mathrm{pH}$ (7.40) of the $\mathrm{SBF}$ and this increase in $\mathrm{pH}$ is justified by the exchange of $\mathrm{Na}^{+} / \mathrm{Ca}^{2+}$ from the glass surface into the solution leading to surface reactions and further formation of silanols ( $\mathrm{Si}-\mathrm{OH}$ ) [37]. During this treatment of the sample with SBF in between 0 to 7 days the maxima of the $\mathrm{pH}=8.25$ was reported after 3 day immersion and further the higher $\mathrm{pH}$ leads to attack of the silica glass network by $\mathrm{OH}^{-}$ions which causes the breaking of Si-O-Si bonds in $\mathrm{SiO}_{2}$ network. Further, after attaining the maxima, the SBF treated sample depicted a decrease in the $\mathrm{pH}$ of the solutionup to 7 days. Sampath has discussed that the reason for this decrease in the $\mathrm{pH}$ would be considered due to the precipitation of $\mathrm{Ca}^{2+}$ ions from the solution to form calcium phosphates and carbonates. Soluble silica is lost in the form of $\mathrm{Si}(\mathrm{OH})_{4}$ to the solution during SBF treatment, leaving more $\mathrm{Si}-\mathrm{OH}$ (silanols) at the glass-solution interface [38]. The condensation and repolymerization gives rise to a silica rich layer. Further, the migration of $\mathrm{Ca}^{2+}$ and $\mathrm{PO}_{4}^{3-}$ from the solution takes place and forms a film on the silica rich layer. Finally, incorporation of hydroxyl and carbonate ions from the solution and crystallization of the $\mathrm{CaO}-\mathrm{P}_{2} \mathrm{O}_{5}$ film leads to crystalline HCA precipitation [19]. The sesequences of the changes in the SBF suggest the formation of an HCA layer on the composite surface, which is in good agreement with earlier reports. It is interesting to note that the ferrite composite does not hinder the $\mathrm{HCA}$ formation and therefore, the $\mathrm{Cu}$-Co ferrite bioactive glass sample demonstrated in vitro HCA formation in SBF.

\section{Surface morphology of ferrite bioactive glass composite be- fore and after soaking in SBF}

Figures 4(a-c) shows the SEM micrographs of the ferrite bioactive glass composite sample before and after soaking in SBF for 7 days. Figure 4(a) shows the $\mathrm{Cu}$-Co ferrite bioactive glass composite before SBF treatment. It can be clearly seen from the image that the grain like structures of ferrite nano particles and irregular shapes of fused bioactive glass samples present in the composite. Figure 4(b) demonstrates the higher magnification image of the composite before immersion in SBF

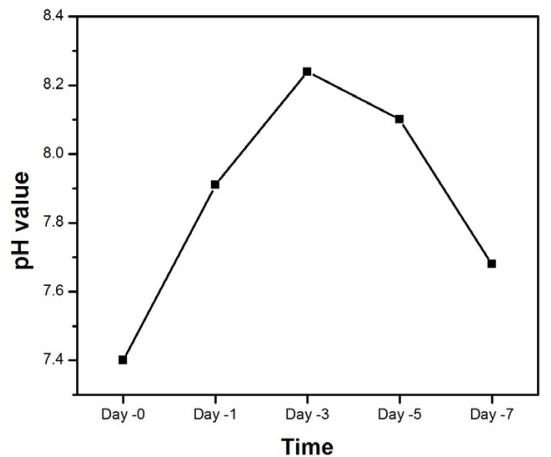

Figure 3: Variation in $\mathrm{pH}$ of the $\mathrm{SBF}$ solution with time for $\mathrm{Co}_{0.2} \mathrm{Cu}_{0.8} \mathrm{Fe}_{2} \mathrm{O}_{4}$ bioactive glass composite

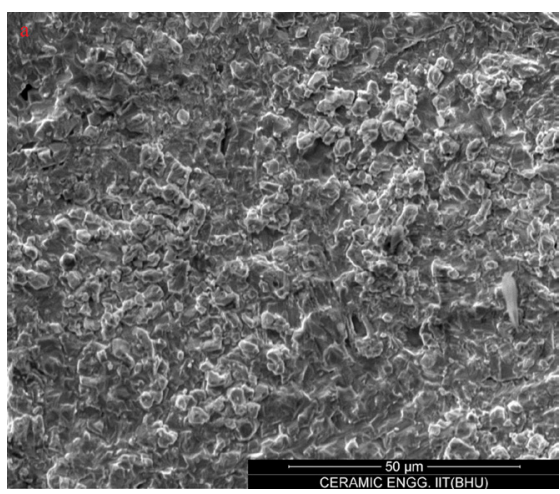

Figure 4a: SEM images of $\mathrm{Co}_{0.2} \mathrm{Cu}_{0.8} \mathrm{Fe}_{2} \mathrm{O}_{4}$ bioactive glass composite

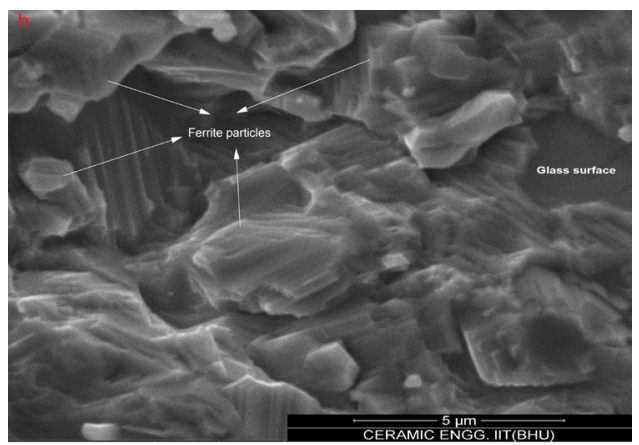

Figure 4b: at higher magnification before SBF treatment

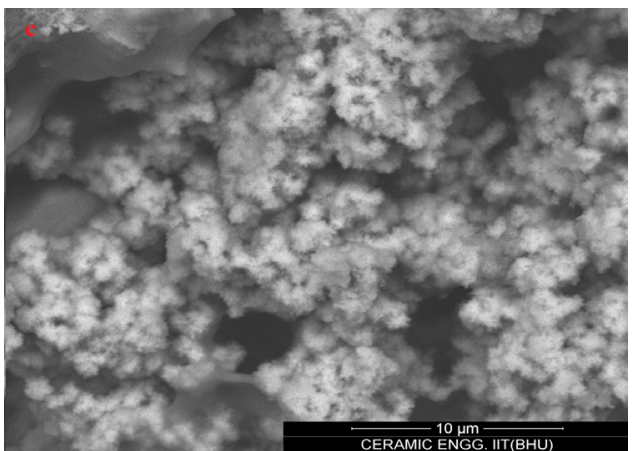

Figure 4c: $\mathrm{Co}_{0.2} \mathrm{Cu}_{0.8} \mathrm{Fe}_{2} \mathrm{O}_{4}$ bioactive glass composite after immersion in SBF for 7 days. 
consisting of rod like structure resemble the ferrite structure and glass surface [15,11]. Figure 4(c) shows the SEM micrographs of composite samples after soaking in SBF for 7 days. A significant change was observed on the surface of the composite sample after immersion in SBF. It is clearly apparent from the figure (figure 4c) that the composite was covered with irregular shape of grounded needle like particles have grown into several agglomerates consisting of an HCA layer $[39,40]$. Therefore, the ferrite material does not effect on HCA formation in the composite. The prepared composite is not a scaffold, but the inherent pores are present due to the mixture of two materials. However, the composite was made by adding bioglass to ferrite which shows some porosity and also some of the ions released from bioglass in SBF would further facilitate the formation of hydroxy carbonate apatite (HCA) layer and bone ingrowth. Hence, the present composite has an added advantage for tissue engineering.

\section{Assessment of HCA formation on the ferrite bioactive glass composite}

The XRD patterns of the composite sample before and after immersion for 7 days in SBF are shown in Figure 5. The presence of crystalline phases in the sintered samples is justified by the peaks which appeared in the XRD patterns of the composite sample. The XRD pattern of the composite reveals the presence of mixed $\mathrm{Cu}-\mathrm{Co}$ spinel ferrite and $\mathrm{Na}_{2} \mathrm{Ca}_{2} \mathrm{Si}_{3} \mathrm{O}_{9}$ (sodium-calcium-silicate) phases before soaking in $\mathrm{SBF}$ and the diffraction peaks of $\mathrm{Na}_{2} \mathrm{Ca}_{2} \mathrm{Si}_{3} \mathrm{O}_{9}$ at $2 \theta=33.5^{\circ}$ and $48.7^{\circ}$ were matched with the standard PDF\#: 22-1455. The previous studies on $45 \mathrm{~S} 5$ bioactive glass sintered at $1000^{\circ} \mathrm{C}$ demonstrated same crystalline phase $[41,42]$. After soakingthe sample in SBF for 7 days, the new peaks emerged at $2 \theta=31.8^{\circ}, 32.8^{\circ}$ and $46.6^{\circ}$ which are regarded as a crystalline phase of $\mathrm{HCA}\left[\mathrm{Ca}_{10}\left(\mathrm{PO}_{4}\right)_{6}(\mathrm{OH})_{2}\right]$ and the desired crystalline phase of HCA was confirmed by JCPDF card numbered 74-0565. The formation of HCA crystalline phases in the composite sample after soaking in SBF can be justified by the presence of sodium-calciumsilicate phase, which favoured much in producing apatite layer $[43,26]$. Furthermore, Jurczyk et al. studied with $10 \mathrm{wt} \%$ of $45 \mathrm{~S} 5$ bioactive glass in the titanium composite sintered at $1150^{\circ} \mathrm{C}$ had confirmed the bioactivity and good biocompatible $[42,44]$. Therefore, the XRD results (Figure 5) of the composite containing $10 \mathrm{wt} \%$ of bioactive glassare in good agreement with the results obtained by earlier workers.

\section{In vitro bioactivity of the ferrite bioactive glass composite by FTIR}

The FTIR spectra of the sintered composite sample before and after immersion for 7 days in SBF are presented in Figure 6. The FTIR spectra of the composite before SBF treatment represents the most characteristic bandsin between $400-500 \mathrm{~cm}^{-1}$ range, which is assigned due to $\mathrm{Si}-\mathrm{O}-\mathrm{Si}$ bending mode of vibration. The peaks in the range 860 940 and $1000-1100 \mathrm{~cm}^{-1}$ are attributed to Si-O and Si-O-Si stretching, respectively. A small bands centered at around $569 \mathrm{~cm}^{-1}$ and $631 \mathrm{~cm}^{-1}$ is characteristic for the metal-oxygen $\left(\mathrm{M}_{\text {tetra }}-\mathrm{O}\right)$ vibration modein the tetrahedral sites indicatingthe formation of spinel phase in the composite [11] Vaidyanathan et al. mentioned that the spectrum of the uncoated sample of cobalt zinc ferrite has shown a strong band in between $635-574 \mathrm{~cm}^{-1}$ which was attributed due to the formation of metal-oxygen bonds in ferrite [18]. After 7 days of immersion in SBF, the spectra of ferrite bioactive glass compositeas shown in Figure 6 indicated the initiation of the calcium phosphate layer formation which is confirmed by the increase in the intensity of vibrational bands at $569 \mathrm{~cm}^{-1}$ and $622 \mathrm{~cm}^{-1}$. Similar observations were also recorded by earlier workers in $45 \mathrm{~S} 5$ bioactive glass $[45,46]$. The peaks at 400 -
$500 \mathrm{~cm}^{-1}$ were attributed to Si-O-Si bending mode of vibration in the spectra of ferrite bioactive glass composite sample. The rise in intensity of the bands at around 936 and $1085 \mathrm{~cm}^{-1}$ in the spectra are attributed to the $\mathrm{Si}-\mathrm{O}$ stretching mode of vibration in the sample, which is due to the presence of more non bridging oxygen $\left(-\mathrm{O}^{-}\right)$. Further, the sample soaked in SBF also showed additional peaks in the range $1421-1631 \mathrm{~cm}$ ${ }^{1}$ which corresponds to $\mathrm{C}=\mathrm{O}$ (stretching mode)and the broad band at about $3418 \mathrm{~cm}^{-1}$ was due to the presence of (hydroxyl) $\mathrm{O}-\mathrm{H}$ groups on the surface,which are clearly confirming the presence of a carbonated hydroxy apatite layer $[43,47]$.

\section{In-vitro cell culture}

The viability and cytotoxicity of $\mathrm{Cu}$-Co ferrite bioactive glass compositewas assessed using MG63 cell lines. The cell viability and cytotoxicity for $\mathrm{Co}_{02} \mathrm{Cu}_{08} \mathrm{Fe}_{2} \mathrm{O}_{4}$ bioactive glass composite have been shown with respect to time in Figures 7,8 respectively. The number of living cells proliferated on the composite surface was determined by MTT assay. In MTT assay, the optical density of the solution was measured to quantify the cell viability/living cell count. Higher optical density represents a larger concentration of living cells. Figure 7 illustrates the cell viability against MG63 cell lines and the results indicate that the cell viability was found to be more than $80 \%$ even after $72 \mathrm{~h}$ of culture. Similarly, the cell cytotoxicity results demonstrate the insignificant cytotoxicity against osteoblast MG-63 cell line as shown in Figure 8.Predominantly, 45S5 bioactive glass has been widely reported that, it possesses excellent cytocompatibility against osteoblast cell lines and is being used in clinical applications $[26,48,49]$. Hoppe studied on the cobalt containing 13-93 bioactive scaffold glasses and demonstrated the surface chemistry on cell attachment and proliferation, which will

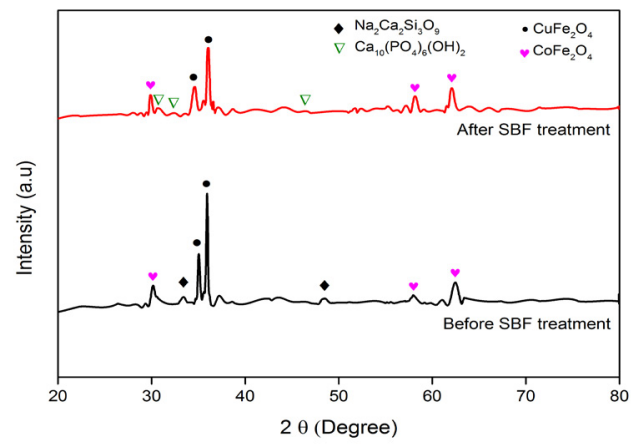

Figure 5: X-Ray diffraction spectra of $\mathrm{Co}_{0} \mathrm{Cu}_{08} \mathrm{Fe}_{2} \mathrm{O}_{4}$ bioactive glass composite before and after soaking in SBF.

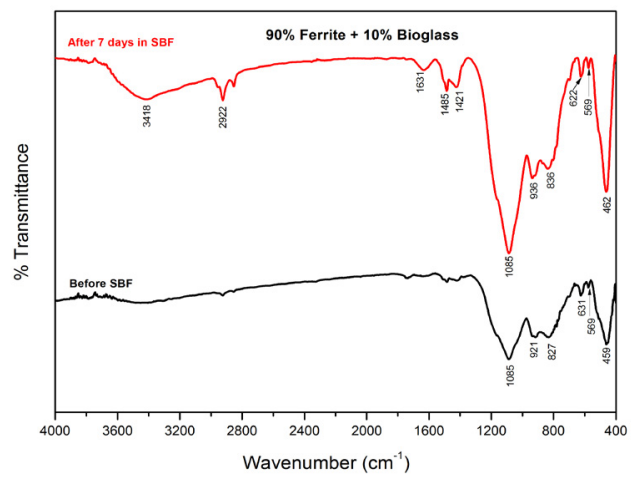

Figure 6: FTIR of $\mathrm{Co}_{0.2} \mathrm{Cu}_{0.8} \mathrm{Fe}_{2} \mathrm{O}_{4}$ bioactive glass composite before and after immersion in SBF for 7 days. 
Citation: Sampath KA, Himanshu T, Kevin B, Singh SP (2016) Structural, Magnetic and In Vitro Bioactivity of Co-Cu Ferrite and Bioglass Composite for Hyperthermia in Bone Tissue Engineering. Bioceram Dev Appl 6: 091. doi:10.4172/2090-5025.100091

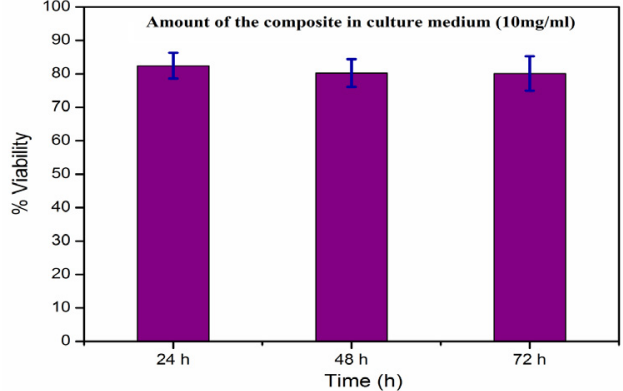

Figure 7: Cell viability of $\mathrm{Co}_{02} \mathrm{Cu}_{0} \mathrm{Fe}_{2} \mathrm{O}_{4}$ bioactive glass composite against MG63 cells.

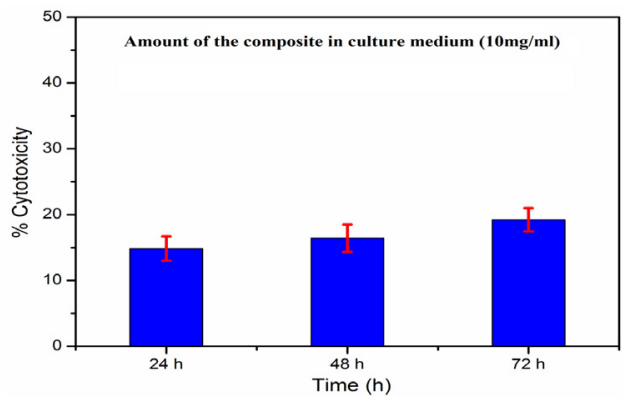

Figure 8: Cell cytotoxicity of $\mathrm{Co}_{02} \mathrm{Cu}_{0.8} \mathrm{Fe}_{2} \mathrm{O}_{4}$ bioactive glass composite against MG63 cells.

further strengthen our results [50]. Thus, the prepared $\mathrm{Cu}$-Co ferrite bioactive glass composite found to be cytocompatible. Moreover, the composite is anticipated to showan antimicrobial environment due to the presence of high concentration of $\mathrm{Cu}^{2+}$ ions in the matrix of the ferrite which will further prohibit the regeneration of tumorous cells at the infected part of the body $[14,15,22,23]$.

\section{Conclusions}

The cobalt-copper mixed ferrite having the composition $\mathrm{Co}_{1}$ $\mathrm{Cu}_{\mathrm{x}} \mathrm{Fe}_{2} \mathrm{O}_{4}(\mathrm{x}=2,4,6$ and 8$)$ was successfully prepared by SHS. The variations in the magnetic and structural properties of mixed ferrites were studied with increasing concentration of $\mathrm{Cu}$ in the cobalt ferrite. The sample $\mathrm{Co}_{0.2} \mathrm{Cu}_{0.8} \mathrm{Fe}_{2} \mathrm{O}_{4}$ demonstrated the mixed spinel ferrite $\left(\mathrm{CuCoFe}_{2} \mathrm{O}_{4}\right)$ phase amongst all and was confirmed by XRD data. The magnetic properties of the mixed ferrites were reported and the $\mathrm{Co}_{0.2} \mathrm{Cu}_{0.8} \mathrm{Fe}_{2} \mathrm{O}_{4}$ sample represented a very much closer linearity of the curve for the softest one. Therefore, it was found to be an appropriate soft ferrite for hyperthermia application. Further, the mixed ferrite and bioactive glass composite was prepared and the precipitation of crystalline HCA layer on the surface of the composite was confirmed by SEM, XRD and FTIR spectrometry and $\mathrm{pH}$ behavior after immersion in SBF. The in-vitro cell culture against MG63 cell lines exhibited that the composite is cytocompatible and non-toxic. Therefore,the $\mathrm{Cu}$ Co ferrite bioactive glass composite has been shown to be a potential matter in bone hyperthermia application. In view of this, the future plan of work is to perform the in vivo test of the composite in an animal and after successful animal trials it can be proposed for clinical applications.

\section{Acknowledgements}

The authors gratefully acknowledge the Head of the Department of Ceramic Engineering, IIT (BHU) and the honorable Director, Indian Institute of Technology (BHU) Varanasi, India for providing necessary facilities for the present research work The author, Sampath Kumar Arepalli is also very much grateful to the University Grants Commission, New Delhi, India (F.14-2(SC)/2010 (SA-III) for providing the Rajiv Gandhi National Fellowship for the research work.

\section{References}

1. Raj K, Moskowitz B, Casciari R (1995) Advances in ferrofluid technology. Journal of Magnetism and Magnetic Materials 149:174-180

2. Hergt R, Dutz S, Müller R, Zeisberger M (2006) Magnetic particle hyperthermia: nanoparticle magnetism and materials development for cancer therapy. Journal of Physics: Condensed Matter.

3. Purushotham S, Ramanujan RV (2010) Thermoresponsive magnetic composite nanomaterials for multimodal cancer therapy. Acta biomaterialia 6: 502-510.

4. Luo S, Wang LF, Ding WJ (2014) Critical review Clinical trials of magnetic induction hyperthermia for treatment of tumours. OA Cancer.

5. Murase K, Takata H, Takeuchi Y, Saito S (2013) Control of the temperature rise in magnetic hyperthermia with use of an external static magnetic field. Physica Medica 29: 624-630.

6. Bull JM (1984) An update on the anticancer effects of a combination of chemotherapy and hyperthermia. Cancer research 44: 4853s-4856s.

7. Jordan A, Scholz R, Wust $P$, Fähling $H$ (1999) Magnetic fluid hyperthermia (MFH): Cancer treatment with AC magnetic field induced excitation of biocompatible superparamagnetic nanoparticles. Journal of Magnetism and Magnetic Materials 201: 413-419.

8. Wust P, Hildebrandt B, Sreenivasa G (2002) Hyperthermia in combined treatment of cancer. The Lancet Oncology 3: 487-497.

9. Valenzuela R (1984) Magnetic Ceramics. In: Cambridge University Press Cambridge pp: 191-212.

10. Amiri S, Shokrollahi H (2013) The role of cobalt ferrite magnetic nanoparticles in medical science. Materials science and engineering $\mathrm{C}$. Materials for biological applications 33: 1-8.

11. Airimioaei M, Palamaru MN, Iordan AR (2014) Structural Investigation and Functional Properties of $\mathrm{Mg} \times \mathrm{Ni} 1-\times \mathrm{Fe}_{2} \mathrm{O}_{4}$ Ferrites. Journal of the American Ceramic Society $97:$ 519-526.

12. Mathew DS, Juang RS (2007) An overview of the structure and magnetism of spinel ferrite nanoparticles and their synthesis in microemulsions. Chemical Engineering Journal 129: 51-65.

13. Hashim M, Shirsath SE, Meena SS (2013) Study of structural and magnetic properties of (Co-Cu)Fe2O4/PANI composites. Materials Chemistry and Physics 141: 406-415.

14. Sanpo N, Wang J, Berndt CC (2013b) Sol-Gel Synthesized Copper-Substituted Cobalt Ferrite Nanoparticles for Biomedical Applications. In: Journal of Nano Research 22: 95-106.

15. Sanpo N, Berndt CC, Wen C, Wang J (2013a) Transition metal-substituted cobalt ferrite nanoparticles for biomedical applications. Acta biomaterialia 9 . 5830-5837.

16. Singhal S (2010) Effect of Zn Substitution on the Magnetic Properties of Cobalt Ferrite Nano Particles Prepared Via Sol-Gel Route. Journal of Electromagnetic Analysis and Applications 2: 376-381.

17. Islam MU, Rana MU, Abbas T (1998) Study of magnetic interactions in Co-ZnFe-O system. Materials Chemistry and Physics 57: 190-193.

18. Vaidyanathan G, Sendhilnathan S, Arulmurugan R (2007) Structural and magnetic properties of $\mathrm{Co}-\mathrm{xZnxFe} \mathrm{O}_{4}$ nanoparticles by co-precipitation method. Journal of Magnetism and Magnetic Materials 313: 293-299.

19. Hench L (1991) Bioceramics: from concept to clinic. Journal of the American Ceramic Society 74: 1487-1510.

20. Kim CY, Clark AE, Hench LL (1989) Early stages of calcium-phosphate layer formation in bioglasses. Journal of Non-Crystalline Solids 113: 195-202.

21. Zhang X, Li XW, Li JG, Sun XD (2014) Preparation and mechanical property of a novel 3D porous magnesium scaffold for bone tissue engineering. Materials Science and Engineering: C 42: 362-367.

22. Wu C, Zhou Y, Xu M, Han P, Chen L, et al.(2013) Copper-containing mesoporous bioactive glass scaffolds with multifunctional properties of angiogenesis capacity, osteostimulation and antibacterial activity. Biomaterials 34: 422-433. 
Citation: Sampath KA, Himanshu T, Kevin B, Singh SP (2016) Structural, Magnetic and In Vitro Bioactivity of Co-Cu Ferrite and Bioglass Composite for Hyperthermia in Bone Tissue Engineering. Bioceram Dev Appl 6: 091. doi:10.4172/2090-5025.100091

23. Goh YF, Alshemary AZ, Akram M, Kadir MRA, Hussain R (2014) Bioactive Glass: An In-Vitro Comparative Study of Doping with Nanoscale Copper and Silver Particles. International Journal of Applied Glass Science 5: 255-266.

24. Cannas C, Falqui A, Musinu A, Peddis D, Piccaluga G (2006) $\mathrm{CoFe}_{2} \mathrm{O}_{4}$ nanocrystalline powders prepared by citrate-gel methods: Synthesis, structure and magnetic properties. Journal of Nanoparticle Research 8: 255-267.

25. Zhong J, Greenspan DC (2000) Processing and properties of sol-gel bioactive glasses. Journal of biomedical materials research 53: 694-701.

26. Chen QZ, Thouas GA (2011) Fabrication and characterization of sol-gel derived 45S5 Bioglass ${ }^{\circledR}$-ceramic scaffolds. Acta biomaterialia 7: 3616-3626.

27. Kokubo T, Takadama $\mathrm{H}$ (2006) How useful is SBF in predicting in vivo bone bioactivity? Biomaterials 27: 2907-2915

28. Kapusetti G, Misra N, Singh V, Swati S, Roy P, et al. (2014) Bone cement based nanohybrid as a super biomaterial for bone healing. Journal of Materials Chemistry B 2:3984-3997.

29. Kapusetti G, Misra N, Singh V, KushwahaRK, Maiti P (2012) Bone cement/ layered double hydroxide nanocomposites as potential biomaterials for joint implant. Journal of biomedical materials research Part A 100:3363-3373.

30. Maaz K, Mumtaz A, Hasanain SK, Ceylan A (2007) Synthesis and magnetic properties of cobalt ferrite $\left(\mathrm{CoFe}_{2} \mathrm{O}_{4}\right)$ nanoparticles prepared by wet chemical route. Journal of Magnetism and Magnetic Materials 308: 289-295.

31. Shi $\mathrm{Y}$, Ding J, Yin $\mathrm{H}$ (2000) $\mathrm{CoFe}_{2} \mathrm{O}$ nanoparticles prepared by the mechanochemical method. Journal of Alloys and Compounds 308: 290-295.

32. Kumar GR (2012) Synthesis, Structural and Magnetic Properties of Copper Substituted Nickel Ferrites by Sol-Gel Method. Materials Sciences and Applications 3: 87-91.

33. Salavati-Niasari M, Mahmoudi T, Sabet M, Soofiand F, Tavakoli F, et al (2012) Synthesis and Characterization of Copper Ferrite Nanocrystals via Coprecipitation. Journal of Cluster Science 23: 1003-1010.

34. Hanh N, Quy OK, Thuy NP, Tung LD, Sipnu L (2003) Synthesis of cobalt ferrite nanocrystallites by the forced hydrolysis method and investigation of their magnetic properties. Physica B: Condensed Matter 327: 382-384.

35. Christensen AN, Lebech B, Andersen NH, Grivel J-C (2014) The crystal structure of paramagnetic copper( ii ) oxalate (CuC 204 ): formation and thermal decomposition of randomly stacked anisotropic nano-sized crystallites. Dalton Trans 43: 16754-16768.

36. Sindhu S, Birajdar D (2013) Structural and magnetic characterization of $\mathrm{Co}^{2+}$ substituted nano structured Copper-Zinc spinel ferrite. IOSR Journal of Applied Physics 3: 33-41
37. Cerruti M, Greenspan D, Powers K (2005) Effect of pH and ionic strength on the reactivity of Bioglass 45S5. Biomaterials 26: 1665-1674.

38. Arepalli SK, Tripathi H, Vyas VK, Jain S, Suman SK, et al. (2015) Influence of barium substitution on bioactivity, thermal and physico-mechanical properties of bioactive glass. Materials Science and Engineering: C 49: 549-559.

39. Beherei H, Mohamed K, El-Bassyouni G (2009) Fabrication and characterization of bioactive glass (45S5)/titania biocomposites. Ceramics International 35 1991-1997

40. Tripathi H, Kumar Hira S, Sampath Kumar A, Gupta U, Manna PP, et al. (2015) Structural characterization and in vitro bioactivity assessment of $\mathrm{SiO}_{2}-\mathrm{CaO}-$ $\mathrm{P}_{2} \mathrm{O}_{5}-\mathrm{K}_{2} \mathrm{O}-\mathrm{Al}_{2} \mathrm{O}_{3}$ glass as bioactive ceramic material. Ceramics Internationa 41: 11756-11769.

41. Chen QZ, Thompson ID, Boccaccini AR (2006) 45S5 Bioglass-derived glassceramic scaffolds for bone tissue engineering. Biomaterials 27: 2414-2425.

42. Jurczyk K, Jurczyk MUU, Niespodziana K, Jakubowicz J (2011a) Titanium$10 \mathrm{wt} \%$ 45S5 Bioglass nanocomposite for biomedical applications. Materials Chemistry and Physics 131: 540-546.

43. Li P, Yang Q, Zhang F, Kokubo T (1992) The effect of residual glassy phase in a bioactive glass-ceramic on the formation of its surface apatite layer in vitro. Journal of Materials Science: Materials in Medicine 3: 452-456.

44. Jurczyk MUU, Jurczyk K, Miklaszewski A (2011b) Nanostructured titanium45S5 Bioglass scaffold composites for medical applications. Materials \& Design 32: 4882-4889.

45. Pirayesh H, Nychka JA (2013) Sol-Gel Synthesis of Bioactive Glass-Ceramic $45 \mathrm{~S} 5$ and its in vitro Dissolution and Mineralization Behavior. Journal of the American Ceramic Society 96: 1643-1650

46. Vyas VK, Kumar AS, Prasad S, Singh SP, Ram P (2015) Bioactivity and mechanical behaviour of cobalt oxide-doped bioactive glass. Bulletin of Materials Science 38: 957-964.

47. Peitl Filho O, LaTorre GP, Hench LL (1996) Effect of crystallization on apatitelayer formation of bioactive glass 45S5. Journal of biomedical materials research 30: 509-514.

48. Kokubo T (1991) Bioactive glass ceramics: properties and applications. Biomaterials 12: 155-163.

49. Hench LL (2006) The story of Bioglass. Journal of materials science Materials in medicine 17: 967-978.

50. Hoppe A, Jokic B, Janackovic D, Fey T, Greil P, et al. (2014) Cobalt-releasing 1393 bioactive glass-derived scaffolds for bone tissue engineering applications. ACS applied materials \& interfaces 6: 2865-2877. 